\title{
The characterization and composting of the municipal solid waste of Riyadh city, Saudi Arabia
}

\author{
S. O. Mutairi, A. M. Ghoneim, A. S. Modaihsh, M. O. Mahjoub \\ \& R. A. Abdel-Aziz \\ Soil Science Department, King Saud University, Saudi Arabia
}

\begin{abstract}
The rapid increase in population and change in life style in Riyadh city, Saudi Arabia have resulted in a dramatic increase in municipal solid waste (MSW) which has recently reached 12,000 tons per day. Most of it (about $85 \%$ ) is disposed as land fill. The present study was initiated to address the problems of MSW disposal and assess the feasibility of the composting of separated organic matter of MSW generated in low, middle and high income districts of Riyadh city. A complete characterization of MSW compost was conducted. Results showed that the average recyclable materials in the three districts were more or less similar. The average organic fraction in the three districts was about $52 \%$. The organic fraction had a number of coli form cells at the starting time of composting which completely disappeared after 21 days from starting the composting process. The composting of MSW resulted in a significant reduction in the volume of municipal solid waste and finally produced earthy smelling soillike material compost. The obtained mature compost contained high levels of the different major elements; $\mathrm{N}(2.0 \%), \mathrm{P}(0.5 \%)$ and $\mathrm{K}(0.25 \%)$. On the other hand, levels of $\mathrm{Cd}, \mathrm{Cr}$ and $\mathrm{Pb}$ were below the standard values suitable for compositing. The $\mathrm{pH}$ and organic matter content of the mature compost were typically 7.70 and $33 \%$, respectively. The $\mathrm{C} / \mathrm{N}$ ratio showed high rates of change during the first 60 days after composting, and then stabilized. In general, the obtained results demonstrated the good quality of the produced compost, which can safely be used for enhancing physical, chemical and biological soil properties.

Keywords: municipal solid waste, composting, Riyadh city, recycle.
\end{abstract}




\section{Introduction}

In recent years, Saudi Arabia witnessed rapid industrialization, high population growth rate and fast urbanization, which have resulted in increased levels of solid waste. The total MSW generation has increased to more than 12 million tons per year [1]. The per capita waste generation is estimated at 1.50 to $1.80 \mathrm{~kg}$ per person per day [2]. Since more than $80 \%$ of the population is concentrated in urban areas, solid waste management is becoming a big challenge especially in mega- cities such as the capital city Riyadh. Solid waste generation in the city of Riyadh exceeds 8 million tons per annum, which gives an indication of the enormity of the problem faced by civic bodies. MSW in Riyadh is mainly disposed of in landfills and incineration. However, deleterious environmental impacts of these practices have promoted municipalities in Saudi Arabia to recycle certain non-organic wastes and compost the organic fraction. This could turn the discarded waste from a liability, to resource.

Waste management technique takes place in many ways viz., landfill, incineration, pyrolysis and gasification, composting and anaerobic digestion [3]. Waste management in Saudi Arabia is characterized by a high percentage of uncollected waste, with most of the waste directed to open or controlled dump sites and strained by limited budgets due to inadequate cost recovery and low service fees. Sorting and composting facilities are being operated with limited capacity [4]. Municipal waste is often generated in greater quantities relative to other forms of solid waste. Diverting the organic portion of the waste stream from landfills minimizes the pollution potential of the residential waste and reduces the quantity of the remaining waste product by $40-60 \%$.

Recycling, reuse, and recovery are still at their infancy in Saudi Arabia, although they are gaining increased consideration. Composting is also gaining increased interest due to the high organic content of raw MSW. Composting is a natural biological process, carried out under controlled conditions; it hastens the decomposition of organic waste and reduces its volume, creating stable, soilenriching humus [5]. In general, composting of organic waste is considered as an effective method to manage this waste type as it targets organic waste in the waste stream and produces a useful end-product. Composting may be defined as part of a sustainable resource management strategy [6]. Furthermore, by transformation of wastes into organic fertilizers, composting would complement sustainable agriculture [7]. On the other hand recycling, enables transforming possible waste materials into a series of products [8]. Hence, sustainability considerations are major driving forces for composting technologies.

The aim of this study was to examine the possibility of composting MSW collected from Riyadh cities, Saudi Arabia municipality as an alternative way of MSW management and assess the nutrient contents of the compost for application in agricultural production. 


\section{Materials and methods}

\subsection{Collection of raw materials}

Samples of raw municipal solid waste were collected from different three districts of Riyadh varying in economic levels, i.e. high, middle and low socioeconomic areas. Ten tons of MSW from each area was collected, properly inspected and then sorted to fractionate the different categories. The average physical characterization of collected MSW samples in Riyadh city is given in Table 1.

Table 1: Physical characteristics of MSW generated in low, middle and high socioeconomic localities of Riyadh city.

\begin{tabular}{|c|c|c|c|c|}
\hline \multirow{2}{*}{ Type } & \multicolumn{3}{|c|}{ Characteristics (\%) } & \multirow{2}{*}{ Average } \\
\hline & Low & Middle & High & \\
\hline Plastics & 16.3 & 22.2 & 15.7 & 18.1 \\
\hline Paper & 16.7 & 20.0 & 23.4 & 20.0 \\
\hline Metals & 2.70 & 2.70 & 3.10 & 2.80 \\
\hline Wood & 1.90 & 1.50 & 0.52 & 1.30 \\
\hline Textile & 2.50 & 1.50 & 2.00 & 2.00 \\
\hline Glass & 2.50 & 2.80 & 3.20 & 2.83 \\
\hline $\begin{array}{c}\text { Compostable } \\
\text { organic } \\
\text { fraction }\end{array}$ & 57.2 & 48.9 & 50.1 & 52.0 \\
\hline \begin{tabular}{c} 
Others \\
\hline
\end{tabular} & 0.20 & 0.40 & 1.98 & 0.97 \\
\hline
\end{tabular}

\subsubsection{MSW compost}

Because of the amount of degradable organic fraction was almost similar in the three districts only one, compost was processed. Three heaps, one ton each was built up in windrows system with mechanically or manual turning of the piles to obtain the compost. The organic fraction of the MSW which mainly constitute of vegetable, fruit and kitchen waste was used to construct heaps to be bioconverted. Treatments were:

- T1: Organic fraction without any accelerator as control,

- T2: Chemical accelerator composed of one ton organic fraction $+40 \mathrm{~kg}$ $\left(\mathrm{NH}_{4}\right)_{2} \mathrm{SO}_{4}+4 \mathrm{~kg}$ superphosphate $+1.25 \mathrm{~kg} \mathrm{~K}_{2} \mathrm{SO}_{4}+35 \mathrm{~kg} \mathrm{CaCO}_{3}$,

- T3. Organic accelerator composed of one ton organic fraction $+200 \mathrm{~kg}$ sludge.

The heaps were moistened to the proper level $(60 \% \mathrm{w} / \mathrm{v})$ for initiating the microbial proliferation. The surface of the heaps were covered with a thin layer of mud and allowed further degradation for 120 days. During this period, the heaps were turned over 3 time intervals at 15,30 and 60 days. The temperature 
of the heaps was frequently recorded. The total weight of introduced organic material for composting and the finished compost weight were calculated by weighing. A representative MSW compost samples were taken from the treatments at different time intervals $(0,7,14,21,30,60$ and 90 days). These processed samples were sub sampled for further chemical analysis.

\subsubsection{Methodology used for the analysis of samples}

The $\mathrm{pH}$ and electrical conductivity of samples were measured (using 1:5 ratio of $\mathrm{w} / \mathrm{v}$ with demonized distilled water) by $\mathrm{pH}$-meter and the electrical conductivity meter respectively. Organic carbon was determined by Total organic carbon (TOC) analyzer. Compost samples were digested with $\mathrm{HNO}_{3}-\mathrm{HClO}_{4}-\mathrm{HF}$, and then total NPK and available NPK concentration in samples were measured. Total micro-elements ( $\mathrm{Fe}, \mathrm{Zn}, \mathrm{Mn}$ and $\mathrm{Cu}$ ) concentration was determined using ICP-AES (Perkin Elmer, 4300DV).

\section{Results and discussion}

The physical characteristics of the solid waste of the three districts is presented in Table 1.The proportion of organic waste to total waste was approximately $52 \%$ of MSW, while paper, plastic, glass, metals, and textiles account for about $43 \%$. Thus close to $85 \%$ of total MSW generated in Riyadh cities is decomposable and recyclable. Presence of significant amount of biodegradable organic materials in raw MSW, indicated that the organic fraction of the refuse was highly suitable for composting process $[2,9]$.

Table 2 shows the $\mathrm{pH}, \mathrm{EC}, \mathrm{OM}$ and changes in nitrogen forms at different time of composting. The $\mathrm{pH}$ values of the composting materials consistently increase as the composting process progresses. The average value of $\mathrm{pH}$ for $\mathrm{T} 1$ was 8.09 , for $\mathrm{T} 2$ as 8.03 and $\mathrm{T} 3$ as 7.81 . The $\mathrm{pH}$ value changes during composting, due to changes in the chemical composition of MSW. In general, the $\mathrm{pH}$ falls around neutral in the beginning due to the formation of organic acids and later rises above neutral because the organic acids are consumed and ammonium is produced $[10,11]$. EC is an important parameter to determine the compost quality as high salt concentration can inhibit the seed germination so it is essential to measure the EC of compost before its application as a soil conditioner. The samples collected from T1 showed average EC value as $3.87 \mathrm{dS}$ $\mathrm{m}^{-1}, \mathrm{~T} 2$ as 4.61 and T3 as $5.57 \mathrm{ds} \mathrm{m}^{-1}$ (Table 2). In the present study the $\mathrm{pH}$ and EC values are within the international limits $[12,13]$. Organic matter content was found as $38 \%-39 \%$ in the samples collected from different treatments. This indicates that $\mathrm{OM}$ is in substantial quantity to make compost out of it Organic matter and organic carbon tended to decrease with increasing the time of composting $[12,14]$ reported that $\mathrm{OM}$ percentage ranges from $30-35 \%$ in MSWC. Organic matter was significantly high and lies within the standard. 
Table 2: Chemical characterization of MSWC at different times of composting. T1; Organic fraction without any accelerator, T2; Organic fraction with chemical accelerator and T3; Organic fraction with organic accelerator.

\begin{tabular}{|c|c|c|c|c|c|}
\hline \multirow[t]{2}{*}{ Treatments } & \multicolumn{4}{|c|}{ Time (Days after composting) } & \multirow[t]{2}{*}{ Mean } \\
\hline & 0 & 30 & 60 & 90 & \\
\hline & \multicolumn{5}{|c|}{$\mathrm{pH}$} \\
\hline $\mathrm{T} 1$ & 7.91 & 7.98 & 8.37 & 8.08 & 8.09 \\
\hline $\mathrm{T} 2$ & 7.82 & 7.84 & 8.52 & 7.92 & 8.03 \\
\hline T3 & 7.46 & 7.69 & 8.26 & 7.84 & 7.81 \\
\hline \multirow[t]{2}{*}{ Mean } & 7.73 & 7.84 & 8.38 & 7.95 & \\
\hline & \multicolumn{5}{|c|}{$\mathrm{EC}\left(\mathrm{dS} \mathrm{m}^{-1}\right)$} \\
\hline $\mathrm{T} 1$ & 2.85 & 3.86 & 4.25 & 4.53 & 3.87 \\
\hline $\mathrm{T} 2$ & 3.60 & 4.65 & 4.97 & 5.22 & 4.61 \\
\hline T3 & 3.96 & 5.87 & 6.12 & 6.33 & 5.57 \\
\hline \multirow[t]{2}{*}{ Mean } & 3.47 & 4.79 & 5.11 & 5.36 & \\
\hline & \multicolumn{5}{|c|}{ Organic Matter (\%) } \\
\hline $\mathrm{T} 1$ & 48.6 & 39.7 & 34.2 & 32.9 & 38.8 \\
\hline $\mathrm{T} 2$ & 48.7 & 38.2 & 35.6 & 33.1 & 38.9 \\
\hline $\mathrm{T} 3$ & 49.8 & 36.9 & 34.2 & 32.3 & 38.3 \\
\hline \multirow[t]{2}{*}{ Mean } & 49.0 & 38.3 & 34.7 & 32.8 & \\
\hline & \multicolumn{5}{|c|}{ Organic Carbon (\%) } \\
\hline $\mathrm{T} 1$ & 28.2 & 23.0 & 19.8 & 19.0 & 22.5 \\
\hline $\mathrm{T} 2$ & 28.3 & 22.1 & 20.7 & 19.2 & 22.6 \\
\hline T3 & 28.9 & 21.4 & 19.8 & 18.7 & 22.2 \\
\hline Mean & 28.5 & 25.5 & 20.1 & 18.9 & \\
\hline
\end{tabular}

\subsection{Total and available NPK, changes in $\mathrm{N}$ forms and $\mathrm{C} / \mathrm{N}$ ratio}

The results in tables 3 and 4 show that the total and available NPK concentration has increased with composting time as $\mathrm{C}$ is utilized by microorganism (Wolkowski [15]). In almost all cases of T3, the highest values were recorded. The concentration of $\mathrm{NH}_{4}{ }^{+}-\mathrm{N}$ in the produced compost tended to decrease while the $\mathrm{NO}_{3}{ }^{-}-\mathrm{N}$ increased with increasing the time of composting. The highest $\mathrm{NH}_{4}{ }^{+}-\mathrm{N}$ content was recorded by $\mathrm{T} 2$, this could be attributed to adding $\mathrm{CaCO}_{3}$ which causes ammonium nitrogen to be lost to the atmosphere as ammonia gas. Not only does this cause odors, it also depletes nitrogen that is better kept in the MSWC for future use by plants. The $\mathrm{C} / \mathrm{N}$ ratio decreased rapidly from an initial average value of 18 in the raw MSW to 12 after only 30 days. The ratio continued to decrease to 10 after 90 days of compositing. The decrease in the $\mathrm{C}: \mathrm{N}$ ratio can be attributed to the transformation of organic carbon into $\mathrm{CO}_{2}$, followed by a reduction in the organic acid content [16]. The $\mathrm{C} / \mathrm{N}$ was found within the acceptable average range of 11-14 since the $\mathrm{C} / \mathrm{N}$ ratio $20-40$ is considered best to be used. Immature compost can cause $\mathrm{N}$ immobilization due to a high compost $\mathrm{C} / \mathrm{N}$ ratio [17]. 
Table 3: Total nitrogen, organic $\mathrm{N}$ and $\mathrm{C} / \mathrm{N}$ ratio of compost at different time of compositing. T1; Organic fraction without any accelerator, T2; Organic fraction with chemical accelerator and T3; Organic fraction with organic accelerator.

\begin{tabular}{|c|c|c|c|c|c|}
\hline Treatments & \multicolumn{4}{|c|}{ Time (Days after composting) } & \multirow[t]{2}{*}{ Mean } \\
\hline & 0 & 30 & 60 & 90 & \\
\hline & \multicolumn{4}{|c|}{ Total N (\%) } & \\
\hline $\mathrm{T} 1$ & 1.40 & 1.96 & 1.76 & 1.82 & 1.74 \\
\hline $\mathrm{T} 2$ & 1.54 & 1.82 & 1.91 & 1.94 & 1.80 \\
\hline T3 & 1.72 & 1.94 & 2.14 & 2.25 & 2.01 \\
\hline \multirow[t]{2}{*}{ Mean } & 1.55 & 1.91 & 1.94 & & \\
\hline & \multicolumn{5}{|c|}{$\mathrm{NH}_{4}^{+}-\mathrm{N}\left(\mathrm{mg} \mathrm{kg}^{-1}\right)$} \\
\hline $\mathrm{T} 1$ & 1970 & 980 & 280 & 210 & 860 \\
\hline $\mathrm{T} 2$ & 4550 & 2380 & 840 & 350 & 2030 \\
\hline T3 & 1960 & 1190 & 290 & 230 & 917 \\
\hline \multirow[t]{2}{*}{ Mean } & 2827 & 1517 & 470 & 263 & \\
\hline & \multicolumn{5}{|c|}{$\mathrm{NO}_{3}{ }^{-}-\mathrm{N}\left(\mathrm{mg} \mathrm{kg}^{-1}\right)$} \\
\hline T1 & 55 & 280 & 370 & 490 & 299 \\
\hline $\mathrm{T} 2$ & 50 & 420 & 540 & 680 & 423 \\
\hline $\mathrm{T} 3$ & 80 & 440 & 560 & 610 & 423 \\
\hline \multirow[t]{2}{*}{ Mean } & 61 & 380 & 490 & 593 & \\
\hline & \multicolumn{5}{|c|}{ Organic N (\%) } \\
\hline $\mathrm{T} 1$ & 1.19 & 1.56 & 1.69 & 1.75 & 1.55 \\
\hline $\mathrm{T} 2$ & 1.08 & 1.54 & 1.77 & 1.83 & 1.56 \\
\hline T3 & 1.52 & 1.78 & 2.05 & 2.17 & 1.88 \\
\hline \multirow[t]{2}{*}{ Mean } & 1.26 & 1.83 & 1.84 & 1.92 & \\
\hline & \multicolumn{5}{|c|}{$\mathrm{C} / \mathrm{N}$ ratio } \\
\hline $\mathrm{T} 1$ & 20.1 & 13.6 & 11.3 & 10.5 & 13.9 \\
\hline $\mathrm{T} 2$ & 18.4 & 12.3 & 10.8 & 9.90 & 12.9 \\
\hline $\mathrm{T} 3$ & 16.8 & 11.0 & 9.27 & 8.32 & 11.3 \\
\hline Mean & 18.4 & 12.3 & 10.5 & 9.57 & \\
\hline
\end{tabular}

\subsection{Bulk concentration of heavy metals}

Table 5 shows the average heavy metals concentration in MSWC samples from the three treatments. The bulk concentration of heavy metals was found highest for T3 as Fe 3159, Zn 580, Mn 399 and $\mathrm{Cu} 185 \mathrm{mg} \mathrm{kg}^{-1}$, followed by T2 as Fe 2526, $\mathrm{Zn} \mathrm{471,} \mathrm{Mn} 308$ and $\mathrm{Cu} 132$ and the least concentration was reported in $\mathrm{T} 1$. The average of bulk heavy metals concentration of $\mathrm{Fe}, \mathrm{Zn}, \mathrm{Mn}$ and $\mathrm{Cu}$ were reported below the standard values suitable for compositing. This shows that this compost can be used as soil fertilizer as its negative impact seems to be less. Hargreaves et al. [18] reported that though total and extractable soil $\mathrm{Cu}$ concentration increased when soil was amended with MSWC but in most cases concentration remained below toxic levels to impact plant growth. 
Table 4: $\quad$ Effect of time of composting on Total and available PK. T1; Organic fraction without any accelerator, T2; Organic fraction with chemical accelerator and T3; Organic fraction with organic accelerator.

\begin{tabular}{|c|c|c|c|c|c|}
\hline Treatments & \multicolumn{4}{|c|}{ Time (Days after composting) } & \multirow[t]{2}{*}{ Mean } \\
\hline & 0 & 30 & 60 & 90 & \\
\hline & \multicolumn{5}{|c|}{ Total P (\%) } \\
\hline $\mathrm{T} 1$ & 0.39 & 0.40 & 0.44 & 0.46 & 0.55 \\
\hline $\mathrm{T} 2$ & 0.48 & 0.50 & 0.52 & 0.53 & 0.51 \\
\hline T3 & 0.47 & 0.50 & 0.52 & 0.54 & 0.51 \\
\hline \multirow[t]{2}{*}{ Mean } & 0.44 & 0.46 & 0.49 & 0.51 & \\
\hline & \multicolumn{5}{|c|}{ Available $\mathrm{P}\left(\mathrm{mg} \mathrm{kg}^{-1}\right)$} \\
\hline $\mathrm{T} 1$ & 8 & 22 & 34 & 42 & 26.5 \\
\hline T2 & 25 & 36 & 80 & 97 & 59.5 \\
\hline T3 & 22 & 35 & 59 & 82 & 49.5 \\
\hline \multirow[t]{2}{*}{ Mean } & 18.3 & 31.0 & 57.5 & 73.7 & \\
\hline & \multicolumn{5}{|c|}{ Total K (\%) } \\
\hline T1 & 0.17 & 0.19 & 0.20 & 0.22 & 0.20 \\
\hline $\mathrm{T} 2$ & 0.20 & 0.24 & 0.26 & 0.29 & 0.25 \\
\hline $\mathrm{T} 3$ & 0.18 & 0.23 & 0.29 & 0.27 & 0.24 \\
\hline \multirow[t]{2}{*}{ Mean } & 0.18 & 0.22 & 0.25 & 0.26 & \\
\hline & \multicolumn{5}{|c|}{ Available $\mathrm{K}\left(\mathrm{mg} \mathrm{kg}^{-1}\right)$} \\
\hline T1 & 811 & 915 & 996 & 1025 & 937 \\
\hline T2 & 974 & 1344 & 1544 & 1641 & 1376 \\
\hline T3 & 872 & 1159 & 1224 & 1333 & 1147 \\
\hline Mean & 886 & 1139 & 1245 & 1333 & \\
\hline
\end{tabular}

\subsection{Parameters of compost maturity}

Compositing of MSW was analyzed in an attempt to define the parameters of maturity. Table 6 shows average chemical composition of finished MSWC in comparison of standard values suitable for composting. The data indicated that, the test compost samples were at par with prescribed international stranded of quality of compost. Organic matter was significantly high (33\%) while $\mathrm{C} / \mathrm{N}$ ratio, $\mathrm{pH}$ and $\mathrm{EC}$ values more or less lies at par with standard. Comparatively high $\mathrm{N}$ content was recorded. The amount of $\mathrm{P}(0.5 \%), \mathrm{K}(0.25 \%)$ and heavy metals content were also found within the acceptable limits as prescribed for soil conditioning. Compost prepared during the present study was found to be a good soil conditioner, eco-friendly and cheap as compared to chemical fertilizer. Therefore, its use in soil may improve the aeration, aggregation, water holding capacity and, and it can furnish soil with nutrients but with their slow release. 
Table 5: Effect of time of composting on Total Fe, $\mathrm{Zn}, \mathrm{Mn}$ and $\mathrm{Cu}$ concentration. T1; Organic fraction without any accelerator, T2; Organic fraction with chemical accelerator and T3; Organic fraction with organic accelerator.

\begin{tabular}{|c|c|c|c|c|c|}
\hline \multirow[t]{2}{*}{ Treatments } & \multicolumn{4}{|c|}{ Time (Days) } & \multirow[t]{2}{*}{ Mean } \\
\hline & 0 & 30 & 60 & 90 & \\
\hline & \multicolumn{5}{|c|}{ Total $\mathrm{Fe}\left(\mathrm{mg} \mathrm{kg}^{-1}\right)$} \\
\hline $\bar{T} 1$ & 2128 & 2247 & 2359 & 2406 & 2285 \\
\hline $\mathrm{T} 2$ & 2288 & 2412 & 2678 & 2726 & 2526 \\
\hline T3 & 2574 & 3188 & 3437 & 3437 & 3159 \\
\hline \multirow[t]{2}{*}{ Mean } & 1621 & 2616 & 2825 & 2856 & \\
\hline & \multicolumn{5}{|c|}{ Total $\mathrm{Zn}\left(\mathrm{mg} \mathrm{kg}^{-1}\right)$} \\
\hline T1 & 354 & 386 & 418 & 543 & 425 \\
\hline $\mathrm{T} 2$ & 387 & 434 & 475 & 590 & 472 \\
\hline T3 & 477 & 524 & 611 & 711 & 581 \\
\hline \multirow[t]{2}{*}{ Mean } & 406 & 448 & 501 & 615 & \\
\hline & \multicolumn{5}{|c|}{ Total Mn $\left(\mathrm{mg} \mathrm{kg}^{-1}\right)$} \\
\hline T1 & 225 & 276 & 312 & 343 & 289 \\
\hline $\mathrm{T} 2$ & 251 & 292 & 334 & 358 & 309 \\
\hline $\mathrm{T} 3$ & 372 & 397 & 408 & 419 & 399 \\
\hline \multirow{2}{*}{ Mean } & 283 & 322 & 351 & 373 & \\
\hline & \multicolumn{5}{|c|}{ Total $\mathrm{Cu}\left(\mathrm{mg} \mathrm{kg}^{-1}\right)$} \\
\hline T1 & 93 & 118 & 134 & 145 & 123 \\
\hline $\mathrm{T} 2$ & 96 & 117 & 151 & 167 & 133 \\
\hline T3 & 134 & 176 & 198 & 234 & 186 \\
\hline Mean & 108 & 137 & 161 & 182 & \\
\hline
\end{tabular}

Table 6: Average chemical composition of produced compost in comparison of those of standard value.

\begin{tabular}{|c|c|c|c|}
\hline Parameters & \begin{tabular}{|l|} 
Average finished \\
compost values
\end{tabular} & $\begin{array}{|lr|}\begin{array}{l}\text { Standard } \\
\text { suitable }\end{array} & \text { values } \\
\text { composting } & \text { for } \\
\end{array}$ & References \\
\hline $\mathrm{pH}$ & 7.70 & 7.30 & [12] \\
\hline $\mathrm{EC}\left(\mathrm{dS} \mathrm{m}^{-1}\right)$ & 5.40 & $>4.0$ & [13] \\
\hline OM (\% dry basis) & 32.7 & $\begin{array}{c}>30 \\
35\end{array}$ & $\begin{array}{l}{[12]} \\
{[14]}\end{array}$ \\
\hline $\begin{array}{llll}\begin{array}{l}\text { Total Nitrogen } \\
\text { basis }\end{array} & \left(\begin{array}{ll}\% & \text { dry } \\
\end{array}\right.\end{array}$ & 2.00 & 1.70 & [12] \\
\hline $\mathrm{C} / \mathrm{N}$ ratio & 9.40 & $\begin{array}{c}<7.00 \\
7.60\end{array}$ & $\begin{array}{l}{[12]} \\
{[14]}\end{array}$ \\
\hline Total P (\% dry basis) & 0.50 & 0.54 & \multirow[t]{2}{*}{ [12] } \\
\hline Total K (\% dry basis) & 0.25 & 0.21 & \\
\hline Total Fe $\left(\mathrm{mg} \mathrm{kg}^{-1}\right)$ & 3034 & 5300 & [18] \\
\hline Total $\mathrm{Zn}\left(\mathrm{mg} \mathrm{kg}^{-1}\right)$ & 627 & 510 & \multirow{5}{*}{ [14] } \\
\hline Total $\mathrm{Cu}\left(\mathrm{mg} \mathrm{kg}^{-1}\right)$ & 190 & 312 & \\
\hline Total Cd( $\left.\mathrm{mg} \mathrm{kg}^{-1}\right)$ & $0-3$ & $2-10$ & \\
\hline Total $\mathrm{Cr}\left(\mathrm{mg} \mathrm{kg}^{-1}\right)$ & $4-48$ & $30-84$ & \\
\hline Total $\mathrm{Pb}\left(\mathrm{mg} \mathrm{kg}^{-1}\right)$ & $67-107$ & $140-170$ & \\
\hline
\end{tabular}




\section{Conclusions}

Based on the findings, it can be concluded that MSW collected from Riyadh city is suitable for compositing due to the presence of high biodegradable organic matter content, acceptable NPK content and $\mathrm{C} / \mathrm{N}$ ratio in the waste. Treating the biodegradable fraction of MSW materials for a controlled decomposition process (composting) stabilizes the putrescible organic matter quickly and produces a soil amendment that can improve sandy soil fertility, soil texture and water holding capacity and decrease the volume of MSW in Saudi Arabia. Using this compost to amend the soil could not only improve soil quality but also serve as an environmentally safe and economically sound method of MSW disposal.

\section{Acknowledgement}

The authors wish to thank King Saud University, Deanship of Scientific Research, College of Food and Agricultural Sciences, Research Centre for supporting this research work.

\section{References}

[1] Alhumoud, J. M. Municipal solid waste recycling in the Gulf cooperation council states. Resources, Conservation and Availability - a review. Austria Environment Agency, Austria 29, 2005.

[2] Al-Mutairi, S. O., (eds). Production of Compost from Municipal Solid Waste in Riyadh City. M.Sc. Thesis. College of Food Sciences and Agriculture, King Saud University, 2009.

[3] Adewale, M. T., Composting as a sustainable waste management technique in developing countries. Journal of Environmental Science and Technology, 4, 93-102, 2011.

[4] AFED. Arab Environment: Future Challenges Arab Forum for Environment and Development (AFED), Beirut, 2008.

[5] Gautam, S. P, Bundela, P. S, Pandey, A. K, Awasthi, M. K. \& Sarsaiya, S. Composting of municipal solid waste of Jabalpur city. Global J. Environ Res., 4, 43-46, 2010.

[6] Faucette, B., (eds). Evaluation of Environmental Benefits and Impacts of Compost and Industry Standard Erosion and Sediment Control Measures Used in Construction Activities. Ph.D. Dissertation, University of Georgia, Atlanta, USA, 2004.

[7] Cathcart, T. P., Wheaton, F. W. \& Brinsfiled, R. B., Optimizing variables affecting composting of blue crab scrap. Agricultural Wastes, 15, 269-286, 1986.

[8] Campbell, J. E., Dielectric properties and influence of conductivity in soils at one to fifty megahertz. Soil Science Society of America Journal, 54, 332-341, 1990. 
[9] Asfari, A. F., Municipal solid waste management in the Arab world with particular reference to GCC Courtiers. Proc. of Oman International Conf.On Waste Management, 2002.

[10] Beck-Friis, B., Smårs, S., Jönsson, H., Eklind, Y. \& Kirchmann, H., Composting of source-separated household organics at different oxygen levels: Gaining an understanding of the emission dynamics. Compost Science \& Utilization, 11, pp. 41-50, 2003.

[11] Prescott, L., Harley, J. P., \& Klein, D. A., ( $5^{\text {th }}$ eds). Water enrichment and toxic algal blooms. In: Microbiology. McGraw-Hill, Singapore, pp. 580, 2003.

[12] Moldes, A., Cendon, Y. \& Barral, M. T., Evaluation of municipal solid waste compost as a plant growing media component by applying mixture design. Bioresource Technology, 98, pp. 3069-3075, 2007.

[13] Bastida, F., Moreno, J. L; Hernandez, T. \& Garcia, C., The long-term effects of the management of a forest soil on its carbon content, microbial biomass and activity under a semi-arid climate. Applied Soil Ecology, 37(1-2), pp. 53-62, 2007.

[14] Herrera, F., Castillo, J. E., Chica, A. F. \& Lopez Bellido, L., Use of municipal solid waste as a growing medium in the nursery production of tomato shoots. Bioresource Technol., 99, pp. 287-296, 2008.

[15] Wolkowski, R., Nitrogen management consideration for land spreading municipal solid waste compost. Environmental Quality, 32(5), pp. 1844-1850, 2003.

[16] Sanmanee, N, Panishkan, K., Obsuwan, K. \& Dharmvanij, S., Study of compost maturity during humification process using UV spectroscopy. World AcadSciEng Technol., 80, pp. 403-405, 2011.

[17] Garcia-Gomez, A., Bernal, M. \& Roig, A., Carbon mineralization and plant growth in soil amended with compost samples at different degrees of maturity. Waste Management Research, 21(2), pp. 161-171, 2003.

[18] Hargreaves, J. C., Adl, M. S. \& Warman, P. R., A review of the use of composted municipal solid waste in agriculture. Agric. Ecosyst., Environ., 123, 1-14, 2008. 